\title{
The Concept and Model of Strategic Leadership and Its Importance in Increasing School Achievement
}

\author{
Fazleen Mohamad, Dr Siti Noor Ismail \\ Universiti Utara Malaysia, 06010 UUM Sintok, Kedah, Malaysia \\ delihonda@yahoo.com \\ Universiti Utara Malaysia, 06010 UUM Sintok, Kedah, Malaysia \\ siti.noor@uum.edu.my
}

\begin{abstract}
Strategic leadership is one of the leaderships practiced by school organizations today. Organizational capabilities and individual characteristics are two key components of strategic leadership that are indispensable to ensure that this strategic leadership can be realized effectively in schools. This article discusses the concept of strategic leadership, domain and elements and theories related to strategic leadership. In addition, this study also attempts to highlight Davies and Davies 2004 strategic leadership model which has nine elements under two key components of strategic leadership i.e. organizational capability and individual characteristics. Furthermore, the final part of the study discusses the importance of strategic leadership in the school organization. An overview of previous studies also shows that strategic leadership has significant relationships with school achievement. Hence, through the practice of strategic leadership that is preached in schools, the line of leadership of the school will be more capable in helping to improve the achievement of their respective schools.
\end{abstract}

Keywords: Strategic Leadership, Organizational Capabilities, Individual Characteristics.

Academic Discipline / Sub Discipline: Education, Leadership

Subject Classification: Education

Analytical Method: Survey

Type: Literary Analysis

Language: English

Date of Submission: 2018-01-20

Date of Acceptance: 2018-02-20

Date of Publication: 2018-03-15

ISSN: 2321-1091

Volume: 12 Issue: 01

Journal: Journal of Social Science Research

Publisher: CIRWORLD

Website: https://cirworld.com

This work is licensed under a Creative Commons Attribution 4.0 International License. 


\section{Introduction}

School is a formal organization that prepares education to the individuals who are categorized as students who will lead the country in the future. This will coincide with The National Education Philosophy which has outlined that education in Malaysia is a continuous effort to produce a balanced individual in terms of physical, emotional, spiritual and intellectual and this individual is expected to be able to contribute to the families, the community, and to the country in the near future. However, a school needs a charismatic leader to lead the institute.

School leadership plays an important role in helping to increase the quality of teaching among teachers. Previous studies have also shown that the success of an organization depends on the leadership of an organization (Jamilah \& Yusof, 2011; Yaakob \& Yahya, 2012). The party with the greatest influence on the success of an organization is the school leaders who is the principal or the headmaster (Jamilah \& Yusof,2011). Thus, schools with the intention of producing excellent individuals of these four aspects of physical, emotional, spiritual and intellectual need to have an authoritative leader. Therefore, one of the things that is outlined in PPPM 2013 - 2025 is about leadership in school that ensures high prestigious leadership is placed in every school. One is said to be a leader when he can produce a vision and a mission of an organization and then bring the inspiration to the employees to jointly achieve that vision (Robbins \& Judge, 2013).

Strategic leadership encompasses the ability to produce a vision and handles the existing resources and energy in preparation to achieve that vision (Hidayah, Sule, Wirasasmita, \& Padmadisastra, 2015). However, it is necessary to go through a series of strategic management processes, and then restructure the organization based on the chosen strategy and build a conducive organizational culture with hope to achieve effective organizational goals. According to Hidayah, Sule, Wirasasmita and Padmadisastra (2015) a leader with strategic leadership features should also have a clear understanding of his environment including the latest technology facilities and how it affects the organization. In this research, a leader with strategic leadership features need to be clear about the environmental factors such as teacher collaboration and the quality of teaching that can directly affect the achievement of their students. This also coincides with the statement from Manish (2014) that leaders who are in this environment, that is strategic leadership, need to identify the situation or practice, skills and the existing ability that have a chance to change, and not to completely break the organization. Therefore, to improve the quality of teaching among teachers, school leaderships and also the cooperation and agreement between teachers play an important role. This shows collaboration among teachers is an important aspect of the success of a program to be implemented specifically on the quality of teaching.

\section{Concept and Definition of Strategic Leadership}

Leadership is a term used to describe someone which uses its influence to influence others with the aim of guiding, structuring and facilitate activities even relationships within a group or organization (University of Van Pretoria, 2013). According to Baharom and Mohammad Johdi (2009), leadership involves unequal distribution of leaders and members of the group. This statement implies that a leader has the right or authority to direct the members in the group he leads. While in education as stated in the Education Development Plan 20132015, leadership means the principals and high-quality support leadership teams will drive the overall performance of the school.

According to Yukl (2006), there are various studies that have been done regarding this leadership. However, the results obtained are not uniform and inconsistent with each other. As a result of this inconsistency, there are various theories about leadership among them are the Transformational Leadership Theory (Bass \& Avolio, 1994), Model Contingency Leadership (Fiedler, 1964), Path-Goal Theory (House, 1996) and Strategic Leadership Model (Adair, 2012; B. Davies, 2004; B. Davies \& Davies, 2005, 2010, B. J. Davies \& Davies, 2004, 2006; Eacott, 2010). Yukl (2010) stated that there were not much theoretical studies about leadership but the main purpose of leadership was to revolve around leaders who influence organizational members to achieve the goals of the organization. 
Strategic leadership based on the model developed by Davies and Davies $(2004,2006)$ is about the strategic leadership at school. In the model it has been explained about what needs to be done as a strategic leader and the characteristics that a leader should adopt in strategic leadership. A person who is able to perform and show characteristics as listed by the model will be categorized as a strategic leader. The nine elements listed in the model are divided into two dimensions: organizational capability and individual features which are strategic orientation, strategic translation, strategic alignment, strategic interaction, strategic capabilities, anxiety, absorption, adaptation and intelligence.

Strategic leadership practiced in schools can help school leaders to plan and carry out repair processes on an on-going basis and in line with the current situation and the plan must be flexible in order to respond with any change (Williams \& Johnson 2013). Meanwhile, according to Manish (2014), strategic leadership is necessary to achieve the goals planned by the superiors with the help of managers and planners. This study was conducted using a strategic leadership model developed by Davies and Davies $(2004,2006)$ based on the dimensions identified by Davies and Davies (2004).

\section{Strategic Leadership Domains and Elements}

Strategic leadership is a type of leadership practiced in a research organization. This type of leadership practice can help improve the quality of teaching of teachers, thus helping to improve school achievement, especially in terms of school average grade (GPS). Hence, to ensure that this kind of leadership can be fully applied in a school, the administrator must first understand what strategic leadership is and how it can be used to help improve school achievement. This strategic leadership involves two key components, which are the components of organizational capabilities and components of individual characteristics (B. J. Davies \& Davies, 2004, 2006).

In Malaysia this strategic leadership measurement was carried out using a measuring tool developed by Hairuddin (2012). This instrument was developed by a lecturer at International Islamic University, Kuala Lumpur, Malaysia based on Davies and Davies 2004, 2006 and 2009 strategic leadership models and in line with the local context. This instrument contains 90 items that include the organizational capability components and individual features components.

Organizational capabilities focus on organizational advantages and their ability to respond to any internal and external changes that occur to the organization (Inan \& Bitici, 2015). According to Mohammad Johdi and Nazifah Alwani (2015) the characteristics of this individual are important in strategic leadership because it can help an organization achieve success especially in the education system.

\section{Strategic Leadership Theories}

Here are the theories about strategic leadership introduced by previous researchers and have also been adopted by some leaders who practice strategic leadership in their organizations: -

i. Wilson (1996) stated that strategic leadership spans a lot of efficiency in management. However, this does not mean that a leader can neglect the matter with management, but a successful firm or organization needs both of these things namely leadership and management to achieve their mission and vision.

ii. Rowe (2001) defines strategic leadership as the ability to influence others voluntarily in making daily decisions related to the organization where this decision will be able to assist the organization's long-term advancement.

iii. Hitt and Ireland (2002) explains that a new type of strategic leadership is needed by a leader to help their organization succeed in a dynamic and uncertain environment today. 
iv. Davies and Davies (2004) explain that in order to enhance strategic leadership at school, two things that can be attributed and addressed are the capabilities of the organization and individual traits. This has been explained more clearly in their journal regarding strategic leadership.

v. Sosik, Jung, Berson, Dionne and Jaussi (2005) inform that linking employees and technology system require superior leaders who can showcase a good and brilliant strategic leadership that he can focus on strategic and employees.

Jansen, Vera and Crossan (2009), strategic leadership is essential for the exploration and exploitation of a new field, by way of influencing the organization's learning and innovation.

\section{The Importance of Strategic Leadership}

Success in the education system, school and students is contributed by various parties including teachers, parents, student efforts and so on. However, the main factor of success is also contributed by the strategic leadership practiced by school leaders (Mohamad Johdi \& Nazifah Alwani, 2015). This proves that strategic leadership is also important in educational organizations.

Strategic leadership is especially desirable in leadership at school to help increase school achievement. Davies and Davies (2004) stated that in his study on strategic leadership that the learning-centred leadership should be placed in a wider organization and strategic context to become more effective over a longer period of time. Hence, according to them the development of strategic leadership capabilities and features play an important role as the strategic leadership model in Figure 1 below: -

ORGANIZATIONAL ABILITY

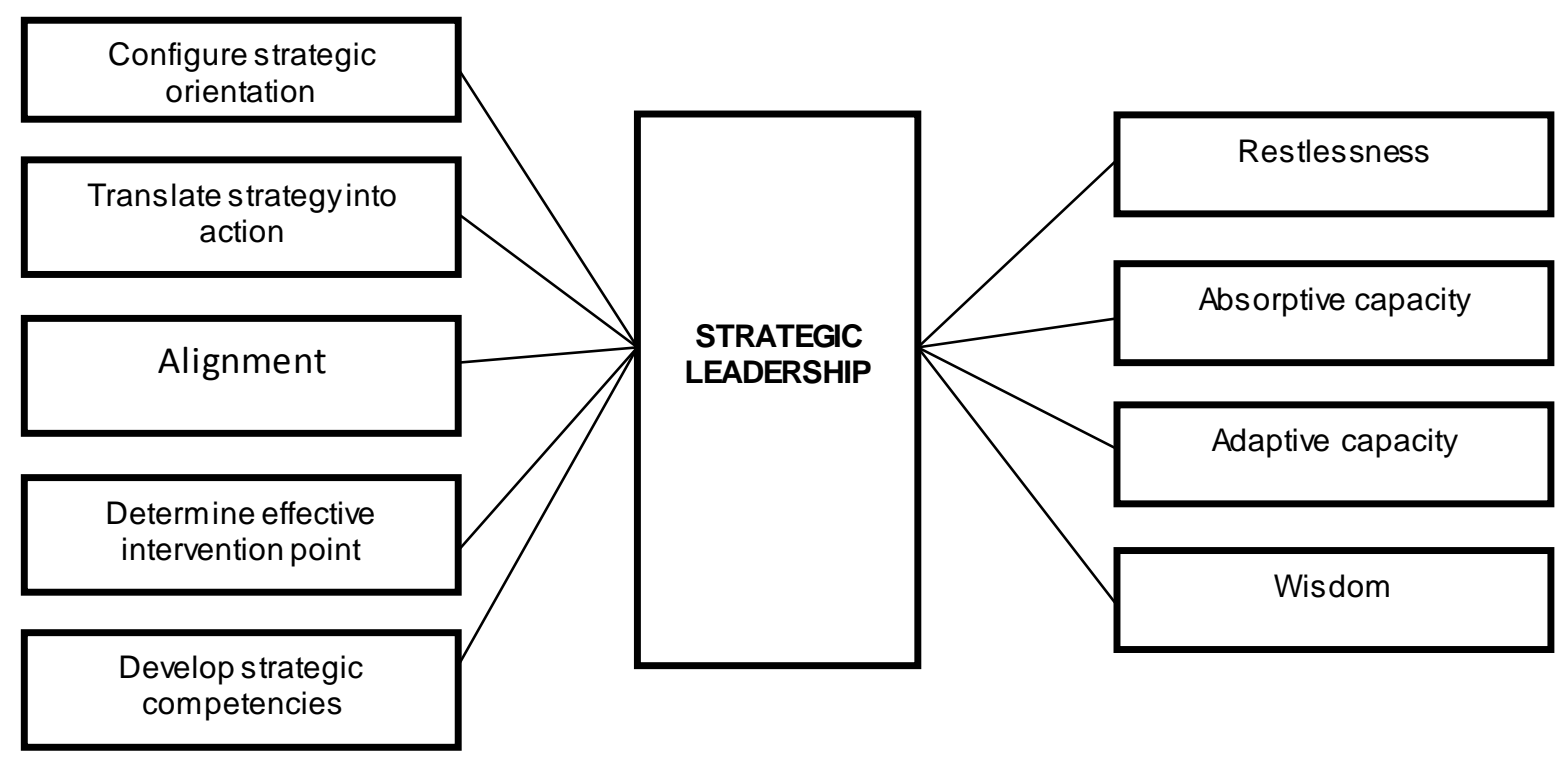

Figure 1. A model of strategic leadership

A study by Ahmad Masrizal and Mohamad Izham (2012) on strategic leadership practices among the boarding school's principals (SBPs) found that SBP principals have managed to position themselves as strategic leaders in good standing, including in organizational capacity components and feature components individual.

The next study by Hairuddin and Aniyath (2015) entitled Do Strategic Leadership and Self Efficacy Among School Leaders Make a Difference? has highlighted nine strategic leadership features which are five elements under the organizational capability components and four elements under individual characteristic component. 
Their findings show that school leaders have used all the elements in strategic leadership and this has become one of the contributors to the achievement and effectiveness of the school.

While the findings from Muazzam, Yahya and Siti Noor's (2016) study on Strategic Leadership and Their Relations with Organizational Change Preparedness have found that the practice leadership among the leaders of an organization is important to ensure the organization's willingness to cope with any future changes. Furthermore, the findings from Waloporn and Wallapha's (2014) study in their journal titled Relationship between Strategic Leadership and School Effectiveness found that there was a positive relationship between strategic leadership and school effectiveness. This shows that strategic leadership plays an important role in producing effective schools.

\section{Conclusion}

Understanding the concept of strategic leadership is important by a leader before he or she applies it in his or her leadership practice. This is because strategic leadership that is in practice will give a positive result in the school's education system, especially with the general country. An effective and excellent school will also be able to produce good strategic leadership practices. Therefore, a leader needs to be absolutely clear about what strategic leadership is and components contained in it as described in the Davies and Davies (2004) model in their journal Strategic Leadership. This model is appropriate to be practiced in school organization as it emphasizes on the strategic leadership practices that should be applied by the leadership line in the school organization.

\section{Acknowledgments}

My heartfelt gratitude to all especially Dr Siti Noor Ismail for contributing to this paper.

\section{References}

1. Adair, J. (2012). Strategic Leadership. Strategic Leadership - Business Book Summaries.

2. Ahmad Masrizal, M., \& Mohd Izham, M. H. (2012). JURNAL PENDIDIKAN DAN LATIHAN Jilid 4 Bil . 02 Disember 2012 Penaung ISSN: 1985-9597 SIDANG EDITOR Ketua Editor Editor Jurnal Pendidikan Dan Latihan.

3. Baharom, M., \& Mohamad Johdi, S. (2009). Kepimpinan pendidikan dalam pembangunan modal insan. Seminar Pembangunan Modal Insan 2009, (1989), 23-24.

4. Bass, B. M, \& Avolio, B. J. (1994). Improving organizational effectiveness through transformational leadership. Sage Publications, Inc.

5. Davies, B. (2004). Developing the strategically focused school. School Leadership \& Management, 24(1), 11-27. https://doi.org/10.1080/1363243042000172796.

6. Davies, B., \& Davies, B. J. (2005). Strategic Leadership Reconsidered. Leadership and Policy in Schools, 4(3), 241-260. https://doi.org/10.1080/15700760500244819.

7. Davies, B., \& Davies, B. J. (2010). The nature and dimensions of strategic leadership. International Studies in Education Administration, 38(1), 5-22. https://doi.org/10.4135/9781473915244.n7.

8. Davies, B. J., \& Davies, B. (2004). Strategic leadership. School Leadership, 24(1), 29-38. https://doi.org/10.1080/1363243042000172804.

9. Davies, B. J., \& Davies, B. (2006). Developing a Model for Strategic Leadership in Schools. Educational $\begin{array}{lllll}\text { Management } \quad \text { Administration } & \text { \& } & \text { Leadership, } & \text { 34(1), }\end{array}$ https://doi.org/10.1177/1741143206059542. 
10. Eacott, S. (2010). Tenure, functional track and strategic leadership. International Journal of Educational Management, 24, 448-458. https://doi.org/10.1108/09513541011056009.

11. Fiedler, F. E. (1964). A contingency model of leadership, effectiveness. In L. Berkowitz (Ed.). Advances in experimental social psychology, 1. New York: Academic Press.

12. Hairuddin, M. A. (2012). The quest for strategic Malaysian Quality National Primary School Leaders. International Journal of Educational Management, 26 (1), 83 - 98.

13. Hairuddin, M. A., \& Aniyath, A. (2015). Do strategic leadership and self efficacy among school leaders make a difference? Asian Social Science, 11(27), 219-234. https://doi.org/10.5539/ass.v11n27p219.

14. Hidayah, N., Sule, E. T., Wirasasmita, Y., \& Padmadisastra, S. (2015). How To Develop Strategic Leadership in Higher Education Institution? International Journal of Economics, Commerce and Management, III(5), 1164-1175.

15. Hitt, M. \& Ireland, R. 2002. The essence of strategic leadership: Managing human and social capital. Journal of Leadership \& Organizational Studies, 9(1): 3-14.

16. House, R. J. (1996). Path-goal theory of leadership: Lessons, legacy, and are formulated theory. Leadership Quarterly, 7(3), 323 - 352. doi:10.1016/s1048-9843(96)90024-7.

17.Inan, G. G., \& Bititci, U. S. (2015). Understanding Organizational Capabilities and Dynamic Capabilities in the Context of Micro Enterprises: A Research Agenda. Procedia - Social and Behavioral Sciences, 210, 310-319. https://doi.org/10.1016/j.sbspro.2015.11.371.

18.Jamilah, A., \& Yusof, B. (2011). Amalan kepimpinan Sekolah Berprestasi Tinggi (SBT) di Malaysia. Journal of Edupress, 1(September), 323-335. Retrieved from http://eprints.utm.my/17080/1/JOE-12011-039.pdf.

19.Jansen, J. J. P., Vera, D., \& Crossan, M. (2009). Strategic leadership for exploration and exploitation: The moderating role of environmental dynamism. Leadership Quarterly, 20(1), 5-18. https://doi.org/10.1016/j.leaqua.2008.11.008.

20. Manish, K. (2014). Strategic Leadership Versus Traditional Organizational Management Today, 2(11), $1-9$.

21. Mohamad Johdi, S., \& Nazifah Alwani, M. (2015). Best Practice of Individual Competences in Strategic Leadership among Principals of Excellent Secondary. International Journal of Scientific and Research Publications, 5(6), 1-7.

22. Mua'azam, M., Yahya, D., \& Siti Noor, I. (2016). Jurnal Kepimpinan Pendidikan. Jurnal Kepimpinan Pendidikan, 3(2), 1-14.

23. Rowe, W. G. (2001). Creating wealth in organizations: The role of strategic leadership. The Academy of Management Executive ,15(1), 81-94. https://doi.org/10.5465/AME.2001.4251395.

24.Sosik, J., Jung, D., Berson, Y., Dionne, S., \& Jaussi, K. 2005. Making all the right connections: The strategic leadership of top executives in high-tech organizations. Organizational Dynamics, 34(1): 4761.

25.University of Van Pretoria. (2013). Leadership Theories and Models. Leadership Theories and Models, 53, 1689-1699. https://doi.org/10.1017/CBO9781107415324.004 
26. Williams, H. S., \& Johnson, T. L. (2013). Strategic leadership in schools. Education Journal, 133(3), 350356.

27.Wilson, I. H. (1996). The 5 compasses of strategic leadership. Strategy \& Leadership, 24(4), 26-31. https://doi.org/10.1108/eb054561.

28. Wiraporn, D., \& Wallapha, A. (2014). Relationship between Strategic Leadership and School Effectiveness. Procedia - Social and Behavioral Sciences, 112(Iceepsy 2013), 982-985. https://doi.org/10.1016/j.sbspro.2014.01.1258.

29. Yaakob, D., \& Yahya, D. (2012). Budaya sekolah, kepemimpinan transformasional dan pencapaian akademik pelajar. Malaysian Journal of Learning and Instruction, 9, 111-139.

30.Yukl, G. (2006). Leadership in Organizations. Journal of Chemical Information and Modeling, 53(9), 1689-1699. https://doi.org/10.1017/СBO9781107415324.004.

31.Yukl, G. (2010). Leadership in organizations, (7th ed.). Englewood Cliffs, NJ: Prentice-Hall.

\section{About Fazleen Mohamad}

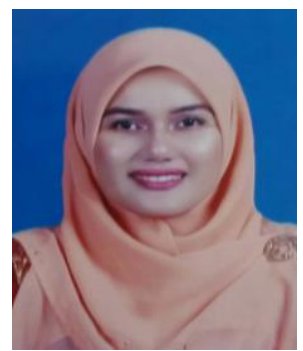

Fazleen Mohamad is an educator at a high school in Kelantan, Malaysia. Currently doing her PhD in Education at Universiti Utara Malaysia. Really into reading and gaining momentum in presenting at seminars and publishing papers in journals. 